\title{
Relationship Between GERD-Q Score with Esophagitis Findings in Endoscopy
}

\author{
Billy Siahaan, Arles, Wirhan Azhari \\ Department of Internal Medicine, Awal Bros Hospital, Pekanbaru
}

\section{Corresponding Author:}

Billy Siahaan. Department of Internal Medicine, Awal Bros Hospital. Jl. A. Yani No. 73 Pekanbaru Indonesia. Phone/facsimile:+62-761 21000. E-mail: billystinggo@gmail.com

\begin{abstract}
Background: Gastro-esophageal reflux disease (GERD) is a disease that is commonly found in daily practice and affecting the patients' quality of life negatively. GERD-Q is a tool in the form of validated questionnaire that is quite useful and easy to use in daily practice to diagnose GERD by symptoms and signs especially in primary care that do not have endoscopy facilities. This study was built to assess the correlation between GERD-Q score and esophagitis finding in upper gastrointestinal endoscopy in Pekanbaru.

Method: This was a prospective cross-sectional study with sample groups of GERD- $Q$ score $\geq 8$ (high GERD-Q score) and GERD-Q score $<8$ (low GERD-Q score) which underwent upper gastrointestinal endoscopy to assess reflux esophagitis. GERD-Q score data were obtained by direct interview.

Results: This study was followed by 65 subjects with reflux esophagitis and 51 non-esophagitis patients that had undergone upper gastrointestinal endoscopy procedure. The 65 subjects with reflux esophagitis were divided into groups based on severity (LA Classification), Grade A 29 subjects (45\%), Grade B 23 subjects (35\%), Grade $C 11$ subjects (16\%), and Grade D 2 subjects (3\%). The result of this study showed that there was a statistically significant association between GERD-Q score $\geq 8$ (high GERD-Q score) and esophagitis findings from upper gastrointestinal endoscopy $(p<0.05, P R=2.6$ ) compare with GERD-Q score $<8$ (low GERD-Q score).

Conclusion: There is a statistically significant association between GERD-Q score and esophagitis findings from endoscopy.
\end{abstract}

Keywords: Gastro-esophageal reflux disease, esophagitis, endoscopy

\begin{abstract}
ABSTRAK
Latar belakang: Penyakit refluks gastro-esofageal (GERD) merupakan penyakit yang umum ditemukan dalam praktek klinis sehari-hari dan berdampak perburukan pada kualitas hidup penderita. GERD-Q, suatu alat berupa kuesioner yang sudah tervalidasi sebagai salah satu alat bantu untuk mendiagnosis GERD merupakan alat yang cukup berguna dan mudah dalam penggunaannya pada lingkup sehari-hari terutama pada fasilitas kesehatan primer dimana pelayanan endoskopi tidak tersedia. Studi ini dilakukan untuk menilai korelasi antara skor GERD-Q dan temuan esophagitis pada endoskopi saluran cerna atas di Pekanbaru.

Metode: Studi ini merupakan penelitian prospective cross-sectional yang dilakukan terhadap 116 subyek dengan gejala GERD pada unit rawat jalan dan kemudian dilakukan endoskopi. Skor GERD-Q dievaluasi pada seluruh subyek dengan menggunakan teknik wawancara .

Hasil: Pada penelitian ini didapatkan 65 subyek dengan refluks esofagitis dan 51 subyek dengan non refluks esofagitis. Dari 65 subyek dengan refluks esofagitis didapatkan Grade A sebanyak 29 kasus (45\%), grade B 23 kasus (35\%), grade C 11 kasus (16\%), dan grade D sebanyak 2 kasus (3\%). Penelitian ini menunjukkan bahwa terdapat hubungan yang signifikan secara statistik antara kategori skor GERD-Q $\geq 8$ terhadap temuan esofagitis pada gastroskopi $(p<0.05, P R=2.6)$ dibandingkan dengan skor GERD- $Q<8$.
\end{abstract}


Simpulan: Didapatkan hubungan antara skor GERD-Q dengan temuan esofagitis pada endoskopi yang signifikan secara statistik tetapi tidak relevan dengan derajat esofagitis.

Kata kunci: penyakit refluks gastro-esofageal, esofagitis, endoskopi

\section{INTRODUCTION}

Gastro-esophageal reflux disease (GERD) is a disease that is commonly found in daily practice and affecting the patients' quality of life negatively. Prevalence of GERD seems to be increasing, which some studies reported the prevalence of GERD are $18.1-27.8 \%$ in North America, 8.8-25.9\% in Europe, 2.5-7.8\% in East Asia, 8.7-33.1\% in Middle East, $11.6 \%$ in Australia, and 23\% in South America. ${ }^{1}$ Prevalence estimates seems affect by geographic variation but East Asia show consistent data that runs under $10 \%$ the study showed. ${ }^{1}$

In Indonesia, there seems to be no complete official report of the prevalence of GERD. A report from Faculty of Medicine, Universitas Indonesia, Cipto Mangunkusumo Hospital Jakarta shows that from 127 subjects that taken upper gastrointestinal endoscopy, $22.8 \%$ ( 30 subjects) have esophagitis. There is also study from Syam et al. that taken from 1718 patients who underwent upper gastrointestinal endoscopy in 5 years (1997-2002), This study also told us that there was a serious increase of esophagitis prevalence from $5.7 \%$ in year 1997 to $25.18 \%$ in year 2002 (average $13.13 \%$ per year). ${ }^{2}$ This number seems to be going to elevate in the future years ahead, considering the worsened lifestyle and habits change in the last decade. The advances in medical technology, especially on gastrointestinal endoscopy technique imaging like narrow band imaging, i-scan and other diagnostic instruments such as 24-hour pH-metry and manometry also may affect this number by increasing diagnostic detection rate for GERD and mucosal break in esophageal gastric junction. ${ }^{2}$

The increasing prevalence of GERD appear to be closely related with multiple factors, such as age, gender, the use of analgesic drugs which are increasingly easy to consume by the general public, and also consumption of certain types of food. ${ }^{3}$ In author's opinion, the culture of eating spicy foods in Riau appears to play a role on prevalence of GERD patients that seek help to the hospital.

Los Angeles Classification system is used to assess the severity level of esophagitis. It was first filed in 1994 and published in 1999. The classification system was created by International Working Group for the Classification of Oesophagitis and was supported by the World Organization of Gastroenterology. ${ }^{4}$
GERD-Q is a questionnaire tool that was developed to help the diagnosis of GERD and to assess response to therapy. This questionnaire was developed based from clinical data from high quality clinical research and also qualitative interview with patients to evaluate the ease in filling out the questionnaire. ${ }^{2}$ GERD-Q is a combination of some questionnaire and was validated by DIAMOND study. Diagnosis accuration rate improvement was reached by this questionnaire, increasing the diagnosis sensitivity and specificity. An analysis from 300 patients in a primary health facility showed that GERD-Q provides $65 \%$ sensitivity and $71 \%$ specificity. ${ }^{5}$ GERD-Q has also been translated into Indonesian language and validated by Simadibrata et al. ${ }^{6}$ The GERD-Q score of 8 or larger is recommended to be the cut-off point to detect individuals with high tendency of suffering GERD. ${ }^{7}$

Some studies showed a strong correlation between GERD-Q and reflux esophagitis, but still appears to be inconsistent. A study by Simarmata et al. showed that the higher the GERD-Q score, the higher probability to find esophagitis. In this study, esophagitis was found in 15 patients in the GERD-Q score $\geq 8$ group (65.2\%) and 2 patients in GERD-Q score $<8$ group $(15.4 \%)$ $(\mathrm{p}<0.005){ }^{8}$

This study were held in Awal Bros Hospital Pekanbaru to find the prevalence of GERD, the esophagitis severity and also the correlation between them. So far, to the best of author's knowledge, there are no studies that have researched the relationship between GERD-Q score with reflux esophagitis in Riau, especially in Pekanbaru City.

\section{METHOD}

This was a prospective cross-sectional study with sample groups of GERD-Q score $\geq 8$ (high GERD-Q score) and GERD-Q score $<8$ (low GERD-Q score) which underwent upper gastrointestinal endoscopy to assess reflux esophagitis. The subjects included in this study were the patients diagnosed with GERD in Awal Bros Hospital Pekanbaru from January until June 2020. Inclusion criteria in this study were patients aged $\geq 18$ years old with GERD symptoms (heartburn and regurgitation) that were willing to sign the informed consent. The exclusion criteria were liver and/or renal impairment, patients with alarm signs (drastic weight 
loss, anemia, and hematemesis melena), coronary arterial disease, alcohol drinker.

GERD-Q score data were obtained by direct interview from the nurse in endoscopy unit. Aside from that, basic characteristic biodata (age, gender, medical history, etc.) and anthropometry (body weight, body height, and body mass index) data were also measured. All of the patients that agreed then undergo upper gastrointestinal endoscopy procedure, where the operator had not known the patient's GERD-Q score that were obtained earlier. Endoscopy procedure was using Olympus Excerra II with Narrow Band Imaging for mucosal break assessment. The endoscopic findings found during the procedure were recorded. Esophagitis was diagnosed and classified according to the Los Angeles Classification.

Table 1. Characteristics of subjects

\begin{tabular}{lccc}
\hline \multirow{2}{*}{ Characteristics } & \multicolumn{2}{c}{ Endoscopy } & \\
\cline { 2 - 3 } & $\begin{array}{c}\text { Esophagitis } \\
\mathbf{n}(\%)\end{array}$ & $\begin{array}{c}\text { Non- } \\
\text { esophagitis } \\
\mathbf{n}(\%)\end{array}$ & Total \\
\hline $\begin{array}{l}\text { Gender } \\
\quad \text { Female }\end{array}$ & $39(60.0)$ & $34(66.7)$ & $73(62.9)$ \\
$\quad$ Male & $26(40.0)$ & $17(33.3)$ & $43(37.1)$ \\
Age & & & \\
$21-30$ & $11(16.9)$ & $4(7.9)$ & $15(12.9)$ \\
$31-40$ & $12(18.5)$ & $7(13.7)$ & $19(16.3)$ \\
$41-50$ & $18(27.7)$ & $23(45.1)$ & $41(80.4)$ \\
$51-60$ & $24(36.9)$ & $17(33.3)$ & $41(80.4)$ \\
Body Mass & & & \\
Index & & & \\
$\quad$ Underweight & $5(7.7)$ & $2(3.9)$ & $7(6.0)$ \\
$\quad$ Normal & $18(27.7)$ & $18(35.3)$ & $36(31.0)$ \\
$\quad$ Overweight & $18(27.7)$ & $17(33.3)$ & $35(30.2)$ \\
$\quad$ Obese & $24(36.9)$ & $14(27.5)$ & $38(32.8)$ \\
\hline Total & $65(56.0)$ & $51(44.0)$ & $116(100)$ \\
\hline
\end{tabular}

Table 2. Association between GERD-Q score category with esophagitis findings from upper gastrointestinal endoscopy

\begin{tabular}{ccccc}
\hline GERD-Q & \multicolumn{2}{c}{ Endoscopy findings } & Total & $\mathbf{p}$ \\
\cline { 2 - 4 } & Esophagitis & $\begin{array}{c}\text { Non- } \\
\text { esophagitis }\end{array}$ & Totannnnn \\
\hline $\begin{array}{c}\text { High } \\
(\text { score } \geq 8) \\
\text { Low }\end{array}$ & 42 & 21 & 61 & 0,012 \\
$($ score $<8)$ & 23 & 30 & 55 & \\
\hline Total & 65 & 51 & 116 & \\
\hline
\end{tabular}

The data obtained was statistically calculated using chi-square test for categorical data and one-way ANOVA test for numerical data of GERD-Q score. The confidence interval used is $95 \%$.

Ethical clearance had been approved by Ethical Committee in Awal Bros Hospital Pekanbaru.

\section{RESULTS}

This study was participated by 116 subjects with GERD symptoms that fulfilled the inclusion and exclusion criteria and were divided into two groups, GERD-Q score $\geq 8$ (61 subjects) and GERD-Q $<8$ (55 subjects). The average of score GERD-Q in this study was 7.74. The average age of the subjects was $45.25 \pm$ 10.14 years old (Table 1 ).

This study also showed that patients with obesity (36.9\%) and overweight (27.7\%) were the largest body mass index (BMI) categories in esophagitis subject group. However, there was no significant correlation between BMI and esophagitis from endoscopy findings $(\mathrm{p}=0.515)($ Table 1$)$.

This study found a statistically significant association between GERD-Q score category with esophagitis findings from upper gastrointestinal endoscopy ( $<<0.05, \mathrm{PR}=2.6)$ (Table 2). However, when the esophagitis group were divided by LA severity classification, the p-value was 0.112 which means there was no correlation between GERD-Q score and esophagitis severity (Table 3 ). The analysis result with the one way anova method also showed no association between mean GERD-Q score and esophagitis severity classification from gastroscopy findings $(p=0.113)($ Table 4, Figure 1).

Table 4. Association between mean GERD-Q score and esophagitis severity classification from gastroscopy findings

\begin{tabular}{lccc}
\hline $\begin{array}{c}\text { Esophagitis severity } \\
\text { classification }\end{array}$ & $\mathbf{n}$ & $\begin{array}{c}\text { GERD-Q score } \\
(\mathbf{n} \pm \text { SD) }\end{array}$ & $\mathbf{p}$ \\
\hline Non-esophagitis & 51 & $7.12 \pm 1.95$ & \\
Grade A Esophagitis & 29 & $8.17 \pm 2.49$ & \\
Grade B Esophagitis & 23 & $8.09 \pm 2.42$ & 0,077 \\
Grade C Esophagitis & 11 & $8.45 \pm 1.29$ & \\
Grade D Esophagitis & 2 & $9.50 \pm 0.71$ & \\
\hline \multicolumn{1}{c}{ Total } & $\mathbf{1 1 6}$ & $\mathbf{7 . 7 4 \pm 2 . 1 8}$ & \\
\hline
\end{tabular}

Table 3. Correlation between GERD-Q score and esophagitis severity

\begin{tabular}{cccccccc}
\hline \multirow{2}{*}{ GERD-Q } & \multicolumn{5}{c}{ Esophagitis classification (LA Classification) } & Total & p-value \\
\cline { 2 - 6 } & $\begin{array}{c}\text { Non- } \\
\text { esophagitis }\end{array}$ & Grade A & Grade B & Grade C & Grade D & 61 & 0,113 \\
\hline High (score $\geq 8)$ & 21 & 19 & 14 & 7 & 2 & 55 & 116 \\
Low (score $<8)$ & 30 & 10 & 9 & 4 & 0 & 2 & 11 \\
\hline Total & 51 & 29 & 23 & & &
\end{tabular}




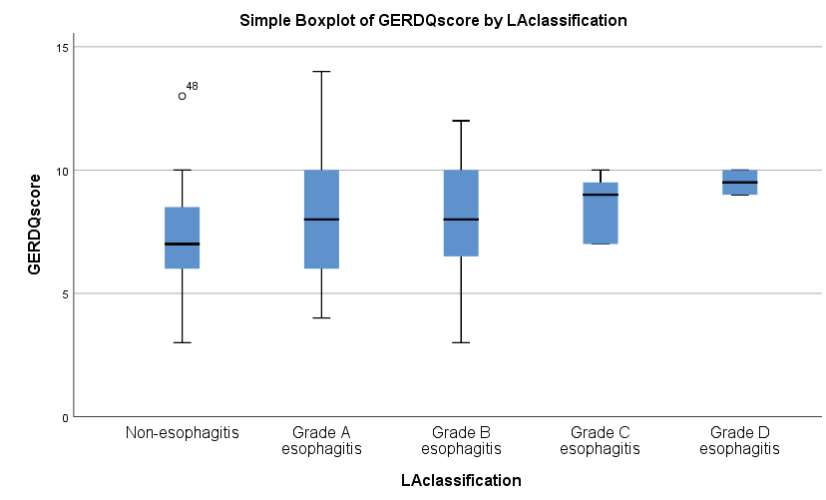

Figure 1. Correlation between GERD-Q Score and esophagitis

\section{DISCUSSION}

In Indonesia, there seems to be no complete official report of the prevalence of GERD. In Riau, data for GERD also had not been reported until this day. Our study showed that from 65 subjects with reflux esophagitis, Grade A and Grade B esophagitis are the largest severity classification groups each group with 29 cases $(45 \%)$ and 23 cases (35\%) respectively. This result is consistent with some other studies, among them is a study in China that found $76.58 \%$ subjects with Grade A esophagitis and $14.12 \%$ subjects with Grade B esophagitis, compared to all subjects with GERD. This result is similar with a study by Simarmata et al. that showed the percentage of Grade A group of $76.5 \%$ and Grade B of $23.5 \%{ }^{8,9}$ These findings meet the promising healing rate for GERD patients in Pekanbaru. In fact, some studies show that there is a significantly lower healing rate in patient with higher grade of erosive esophagitis (Los Angeles Grade $\mathrm{C}$ and D) as opposed to those with lower grades of erosive esophagitis (Grade A and B).${ }^{10}$ The mechanism is related with the higher degree esophageal acid exposure and low amplitude of esophageal contraction in severe grade esophagitis. So, it is well accepted that the poor pathophysiology associated with severe erosive esophagitis leads to poor healing rates. ${ }^{11}$

This study also showed that patients with obesity (36.9\%) and overweight (27.7\%) were the largest body mass index (BMI) categories in esophagitis subject group. However, there was no significant correlation between BMI and esophagitis from endoscopy findings $(p=0.515)$. Existing studies that assess the correlation of BMI and GERD still appear to be inconsistent, It is said that the higher BMI has a strong evidence of correlation with GERD and more than 25 clinical studies supported this. ${ }^{12}$ In Indonesia, a research by Abdullah et al show a significant correlation between BMI and GERD incidents. ${ }^{13}$ Nevertheless, studies by Simarmata et al and Puspita et al, do not show a significant correlation between BMI and GERD, just like this study, so that there are no absolute conclustion up until now. ${ }^{8,14}$

This study found a statistically significant correlation between GERD-Q score category with esophagitis findings from upper gastrointestinal endoscopy $(p<0.05)$. From statistical calculation obtained the Prevalence Risk (PR) value 2.6, so it can be said that subjects with GERD-Q score $\geq 8$ have a risk for reflux esophagitis 2.6 times greater than the subjects with GERD-Q score $<8$. This result is in line with the study from Wang et al. that showed significant correlation between GERD-Q score and esophagitis in China $(\mathrm{p}<0.05) .{ }^{9}$ Another study in China by Bai et al. also found the increase of the proportion of reflux esophagitis patients as the GERD-Q score increasing. ${ }^{15}$ This indicates that the higher GERD-Q score is likely to cause higher probability of reflux esophagitis from endoscopy findings and it can be used as a clue to more aggrieve management in patients with high GERD-Q score, especially in primary healthcare facility that are not capable to perform endoscopy. Other than that, it appears that the relevance and applicability of Indonesian language version of GERD-Q is pretty well although performed in regions with different ethnicity, culture, and dialect.

Meanwhile, this study failed to prove the correlation between GERD-Q score and the severity classification of reflux esophagitis in endoscopy $(p=0.113)$. This result shows different result from a study by Wang et al. that found a positive correlation between GERD-Q and Esophagitis severity classification. Some things that might have caused this are the insufficient sample size and subjects characteristic difference such as in age or ethnicity. The average age of the subjects in this study is $45.25 \pm 10.14$, while the study of Wang et al have the average age of $53.72 \pm 11.99 .{ }^{9}$

\section{CONCLUSION}

This study showed the relationship between GERD-Q score and esophagitis findings from endoscopy in patients with GERD symptoms in Awalbros Hospital Pekanbaru. Subjects with GERD-Q score $\geq 8$ have a risk by 2.6 times greater than subjects with GERD-Q score $<8$. We do not found any correlation between GERD-Q score and severity of Esophagitis.

\section{REFERENCES}

1. El-Serag HB, Sweet S, Winchester CC. Update on the epidemiology of gastro-oesophageal reflux disease: a systematic review. Gut 2014;63:871-80. 
2. National Consensus on the Management of Gastroesophageal Reflux Disease in Indonesia the Indonesian Society of Gastroenterology 2014;46:3.

3. Jarosz M, Taraszewska A. Risk factors for gastroesophageal reflux disease: the role of diet. Prz Gastroenterol 2014;9:297301 .

4. Lundell LR, Dent J, Bennett JR, Blum AL, Armtrong D, Galmiche JP, et al. Endoscopic Assessment of Oesophagitis: Clinical and Functional Correlates and Further Validation of the Los Angeles Classification Gut, 45, 1999.p.172-180

5. Jones R, Junghard O, Dent J, Vakil N, Halling K, Wenerson B, et al. Development of the GERDQ, a tool for the diagnosis and manadement of gastro-esophageal reflux disease in primary care. Aliment Pharmacol Ther 2009;30:1030-8

6. Simadibrata M, Rani A, Adi P, Djumhana A, Abdullah M. The gastro-esophageal reflux disease questionnaire using Indonesian language: a language validation survey. Med J Indones 2011;20:125-30.

7. Halling K. Development of an enhanced questionnaire for diangosis of gastroesophageal reflux disease based on the reflux disease questionnaire, the GERD Impact Scale and the Gastrointestinal Symptom Rating Scale. Gut 2007;56:A209: Abstract: TUE-G- 88

8. Simarmata DO, Wahyudi Y, Bestari MB, Supriadi R. Relationship between Gastroesophageal reflux disease questionnaire (GERD-Q) score and reflux oesophagitis in gastroesophageal reflux disease (GERD) suspected patients in Bandung. Indones J Gastroenterol Hepatol Dig Endosc 2019;20:3.

9. Wang M, Zhang JZ, Kang XJ, Li L, Huang XL, Aihemaijiang K, et al. Relevance between GerdQ score and the severity of Refluks Esophagitis in Ughyur and Han Chinese. Oncotarget 2017;8:74371-7.

10. Castell DO, Kahrilas PJ, Richter JE, Vakil NB, Johnson DA, Zuckerman S, et al. Esomeprazole (40 mg) compared with lansoprazole $(30 \mathrm{mg})$ in the treatment of erosive esophagitis. Am J Gastroenterol 2002;97:575-83.

11. Coenraad M, Masclee AA, Straathof JW, Ganesh S, Griffinen G, Lamers CB. Is Barret's Esophagus characterized more pronounced acid reflux than severe esophagitis? Am J Gastroenterol 1998;93:1068-72.

12. Rosaida MS, Goh KL. Gastro-oesophageal reflux disease, reflux oesophagitis and non-erosive reflux disease in a multiracial Asian population: a prospective, endoscopy based study. Eur J Gastroenterol Hepatol 2004;16:495-501

13. Abdullah M, Syam AF, Fauzi A, Renaldi K, Maulahela H, Utari AP. Prevalence, risk Factors and socio-epidemiological study of gastroesophageal reflux disease: an urban population based study in Indonesia. Asian J Epidemiol 2016;9:18-23.

14. Puspita FC, Putri LA, Rahardja C, Utari AP, Syam AF. Prevalence of gastroesophageal reflux disease and its risk factors in rural area. Indones J Gastroenterol Hepatol Dig Endosc 2017; 18:9-14.

15. Bai Y, Du Y,Zou D, Jin Z, Zhan X, Li ZS, et al. Gastroesophageal reflux disease questionnaire (GERD-Q) in real world practice: a national multicenter survey on 8065 patients. J Gastroenterol Hepatol 2013;28:626-31. 